\title{
1008 Contrast enhanced cardiovascular magnetic resonance imaging prior to prophylactic implantation of a cardioverter/defibrillator identifies patients with increased risk for ventricular arrhythmias
}

Philipp Boyé*1, Udo Zacharzowsky², Hassan Abdel-Aty', Alexander Schirdewan ${ }^{2}$, Rainer Dietz ${ }^{3}$ and Jeanette Schulz-Menger ${ }^{1}$

\author{
Address: ${ }^{1}$ Cardiac MRI Team, Charité University Berlin, Berlin, Germany, ${ }^{2}$ Department of Electrophysiology, Charité University Berlin, Berlin, \\ Germany and ${ }^{3}$ Franz Volhard Clinic, Charité University Berlin, Berlin, Germany \\ * Corresponding author
}

from I th Annual SCMR Scientific Sessions

Los Angeles, CA, USA. I-3 February 2008

Published: 22 October 2008

Journal of Cardiovascular Magnetic Resonance 2008, I0(Suppl I):AI33 doi:I0.I I86/I532-429X-I0-SI-AI 33

This abstract is available from: http://jcmr-online.com/content/I0/SI/AI33

(c) 2008 Boyé et al; licensee BioMed Central Ltd.

\section{Introduction}

Prophylactic implantation of a cardioverter/defibrillator (ICD) has been shown to reduce mortality in patients with chronic myocardial infarction (CMI) and an increased risk for life threatening ventricular arrhythmia (VA). VA is related to infarct size and seems to be related to infarct morphology. Contrast enhanced cardiovascular magnetic resonance imaging (ceCMR) can detect and quantify myocardial fibrosis in the setting of CMI and might therefore be a valuable tool for more accurate risk stratification in this setting.

\section{Purpose}

ceCMR can identify the subgroup developing VA in patients with prophylactic ICD implantation following MADIT criteria.

\section{Methods}

We prospectively enrolled 50 patients ( 47 males, age $68 \pm$ 10 years) with CMI and clinical indication for ICD therapy following MADIT criteria. Prior to implantation $(28 \pm$ 72 days) patients were investigated on a $1.5 \mathrm{~T}$ clinical scanner to assess left ventricular function (LVEF) and late hyperenhancement for quantitative assessment of infarct morphology including total infarct mass, infarct mass related to LV mass, and the degree of transmurality defined by transmural to non-transmural extent in each scar (sequence: inversion recovery gradient echo; matrix $256 \times 148$, imaging 10-30 min after $0.2 \mu \mathrm{g} / \mathrm{kg}$ gadolinium DTPA; short axis stack; full coverage of the LV, no gap; slice thickness $6 \mathrm{~mm}$ ). After implantation, patients were followed up including ICD readout after 3 and than every 6 months for a mean of $692 \pm 292$ days. ICD data were evaluated by an experienced electrophysiologist. Primary endpoint was the occurrence of an appropriate discharge (DC), antitachycard pacing (ATP) or death from cardiac cause.

\section{Results}

The endpoint occurred in 9 cases (5 DC, 3 ATP, 1 death). There was no significant association between the endpoint and LVEF ( $31 \pm 9$ vs. $31 \pm 11, \mathrm{p}=0.97)$, total infarct mass $(50 \pm 19$ vs $53 \pm 34 \mathrm{~g}, \mathrm{p}=0.78)$ or infarct size related to left ventricular mass $(29 \pm 6 \%$ vs. $30 \pm 16, p=0.87)$. The degree of transmurality was significantly associated with the occurrence of the endpoint. Scars with mainly transmural $(>75 \%)$ or strictly subendocardial extent $(<$ $50 \%$ ) were less likely to show ventricular arrhythmia than scars with a transmural extent of 50-75\% (Chi-Square $\mathrm{p}=$ $0.035)$. 


\section{Conclusion}

In patients fulfilling MADIT criteria ceCMR could identify a subgroup at higher risk for VA. These preliminary results support the hypothesis that patients with large infarcts of mainly non-transmural extent are at increased risk for VA. Larger trials are needed to confirm this finding.

Publish with Bio Med Central and every scientist can read your work free of charge

"BioMed Central will be the most significant development for disseminating the results of biomedical research in our lifetime. " Sir Paul Nurse, Cancer Research UK

Your research papers will be:

- available free of charge to the entire biomedical community

- peer reviewed and published immediately upon acceptance

- cited in PubMed and archived on PubMed Central

- yours - you keep the copyright

Submit your manuscript here:

http://www.biomedcentral.com/info/publishing_adv.asp 